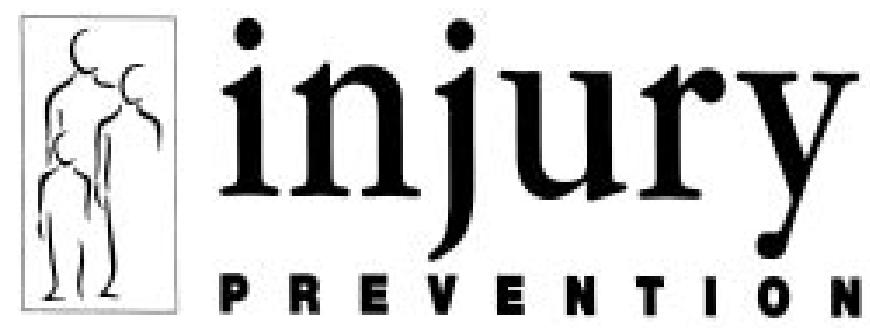

Journal of the International Society for Child and Adolescent Injury Prevention

\title{
Editorials
}

\section{Should-be readers: reaching the unconverted}

Over the past year I have given several lectures that began with reflections on whether I was preaching to the converted or to the choir. As I pointed out, the choir in many churches may include some who are simply good singers but not necessarily members of the same faith as the congregation. They may even be skeptics or agnostics. Talking about injury prevention to audiences who all believe in the message, is easy; far more daunting is trying to reach those who are not in the least convinced that injury prevention is a serious issue.

The same situation applies to readers of this journal. Most are, to use a related metaphor, converts. In fact, I believe most readers are fervent zealots, doing all they possibly can to get the message to all who will listen-that this is a serious and tragic problem because the pain and suffering associated with an injury is so often needless. The prevention of injuries is also relatively easy compared with the prevention of most other conditions. The converts must continue to change how others view the injury epidemic.

There are far too many others, however, who should be reading this journal who do not. Some are colleagues with similar backgrounds to current readers who, for one reason or another, have not yet discovered the journal. For them, a simple prod should do the trick.

Much more challenging are those in other disciplines whom we have failed to reach or failed to convert. During the past year, the board has worked hard to get our message to the former. The latter remain to be convinced that Injury Prevention has much to offer.

It is, of course, embarrassing for an editor to be touting his own publication. Nevertheless, for information of the kind the journal provides to serve its purpose, it must be as widely read as possible. We must continue to reach out to these "would-be" readers. They come in many guises.

Of special importance are front line workers who are not researchers and who may be intimidated by some of the scientific elements found in original articles. It is so important that the bridge between researchers and prevention practitioners be crossed, that I view this as the most formidable of the challenges I face as an editor. To this end, I try hard to ensure that jargon is minimized and insist that most papers conclude with a section headed "implications for prevention". Unfortunately, it is evident that more needs to be done. In the future I intend to offer a personal interpretation of some of the more important findings that bear on prevention practise or policy.

There are also many others who should be regular readers-that is, subscribers. In no particular order they include engineers, environmental designers, urban planners, surgeons, public health workers, and, of course, policy makers. Similarly, those dedicated to violence prevention should find much of interest in the pages of this journal. Many of these groups have their own journals, but I urge that they move beyond the often narrow confines of their disciplines to include this interdisciplinary publication whose main focus is prevention.

Surgeons, especially trauma surgeons and those who specialize in emergency medicine, come closest to the horrors of injuries. Few fail to accept that most damage to tissues need not have happened. It is not surprising that many of the leaders in injury prevention are surgeons who have seen this light. They include David Bass in South Africa, Marty Eichelberger and David Wesson in the US, Louis Francescutti and Rob Conn in Canada, David Yates in the UK, and many others. I assume most of these and their colleagues regularly read excellent journals like Trauma or Injury - largely dedicated to the repair of wounds - but not to their prevention. More surgeons should be reading Injury Prevention.

The third group of should-be readers are those in public health. It is inconceivable that anyone working in this discipline would not accept the importance of injuries in this context. Yet, many public health officers are not subscribers and thus are unable to convey to their staff the most recent developments with respect to both risks and preventive measures.

Finally, although it may seem far fetched to some, it seems reasonable to suggest that government departments involved in any way with injury prevention should have this journal in their libraries. 


\section{Why economic arguments don't work (as well as they should)}

Self interest is the most compelling of all motivations. The most effective way of changing behaviour is to reward (or penalize). This rule applies equally to individuals as to groups, including governments and government departments. If a course of action makes any branch of government richer-or less poor-it seems logical that such action should be endorsed.

Accordingly, it makes sense to assume that economic data related to injury prevention should be highly persuasive in influencing the decisions of health departments. There are now a growing number of cost-benefit reports from various countries, including the US, Canada, and Australia. In spite of their limitations, all reports agree that overwhelming savings follow from relatively inexpensive injury prevention strategies. Nevertheless, few governments have responded accordingly. Why not? What possi- ble explanations can there be for their failing to act in the national self interest?

To my way of thinking, the answer is simple. The branch of government that benefits most from a reduction in injuries is that which pays for the care of the victims. Yet, the range of options open to health departments alone, that is, without the help of colleagues in transport or product safety, for example, is limited. Thus, we face a paradox: transport would have to spend more money to achieve greater safety, but health would be the main beneficiary. In an enlightened society, this is how government should operate, with each department operating for the collective good. Unfortunately we can only conclude that so little is spent on more safety measures, such as enforcing speed limits, because such enlightenment is missing.

\section{An accident that need not have happened}

That quotation from recent news coverage of the terrible tragedy that took place at Paddington Station in London early in October says it all. Two trains collided, killing 30 and injuring many others. As is true for most such events, the evidence strongly suggests that what happened could-and should-have been prevented. Following an earlier similar event, a review committee recommended that a critical red light signal be made more visible and that other essential safety measures be taken. Sadly, neither recommendation was implemented. Whether, as some have suggested, failure to act was in part a consequence of the privatization of the railways in Britain, is not possible to prove. What is clear, however, is that horrible events such as this are doubly tragic if they fail to teach vitally important lessons about safety. The public should be outraged by the apparent indifference of those responsible. There is no conceivable reason why injuries that have a clear pattern should happen more than once. The staff and board of the journal extend condolences to all those affected by this terrible event. I feel certain they join me in urging, in the strongest possible terms, that steps be taken immediately to ensure that there is not yet another such tragedy in future.

\section{Other less easily preventable "accidents": earthquakes}

The thoughts and sympathies of journal staff also extend to those in Turkey, Taiwan, and Greece where recent earthquakes have resulted in many deaths and serious injuries. It is easy to concede that earthquakes, like being struck by lightning, are good examples of genuine "accidents" in the narrow sense.

Nevertheless, from the reports I read it may be that even in the case of earthquakes the consequences need not have been as severe. The very fact that homes in the less affluent sections of the areas involved in the three countries were the most badly damaged, suggests that more stringent construction codes are needed or should have been more rigidly enforced.

One wonders too about the adequacy of tertiary prevention measures and preparedness in such situations. No one can prevent an earthquake; much more can be done to diminish its consequences.

\section{Rewarding authors}

Traditionally, contributors to scientific journals are not paid. Their rewards are limited to the opportunity to share their findings and to whatever academic kudos may follow. Similarly, the essential contributions of peer reviewers are also not remunerated. In effect, journal publishers bear the costs of the peer review process and, of course, the cost of printing and distributing copy. Following the example of the BMF, Injury Prevention will, in future, try to redress this imbalance (at least with respect to contributors) by sharing some of the profit from reprint sales.
Although an unlikely event, a small percentage of reprint or translation orders worth more than $£ 1000$ will be returned to authors. (It has not yet been decided how large is "small".)

This new arrangement came about after closer scrutiny of copyright agreements. In the past, these agreements have obliged authors to assign copyright to the publisher. Although many advantages to both the authors and the publishers arose from this arrangement, the alternatives being enacted seem fairer and may prove even more advantageous. In future, Injury Prevention will not ask 
for copyright but instead will request an exclusive licence. We propose that the rights ceded by the licence would revert to authors if they have not been exploited within one year after publication. Authors no longer need to request permission to use their material for any non-

\section{Thanking reviewers}

At the end of each year it is customary to thank all those who contribute so critically to this journal's success. First, and foremost, the entire editorial board deserves more thanks than most readers suspect. Unlike many other journals, our is a "working board" and hard working at that. Almost every paper submitted to us is reviewed by at least one editor as well as by at least one other expert reviewer. For the most part, board reviewers provide prompt and constructive comments. To all of them, my heartfelt thanks. I am especially grateful to the deputy and associate editors to whom I turn regularly for advice on all manner of issues. The contributions of the regional editors and regional correspondents give the journal its special, distinctive flavour-one that most readers greatly appreciate. These, too, deserve great thanks.

During this year of change, we have replaced many faithful, long serving members of the board with new blood. To the former, my great thanks for a job commercial use. The most likely application of this is posting on personal or institutional web sites - a practice we encourage.

Your comments on this decision are welcome. As is true for most decisions, it can be reversed.

well done.Special thanks is owing to Jan Shield who, for the past four years, has written Splinters \& Fragments. This popular section always arrived on time and was flawlessly written, spiced with sharp observations, and occasionally laced with humour. Sadly, Jan has changed positions and is no longer able to write this column. We shall search for a replacement, but hers is a tough act to follow.

To the new board members, a warm welcome and the hope that the shock of the workload has not been too great. I am deeply indebted to every member of the board and trust I will be forgiven if, in the interests of space, I do not list each here. Simply look at the masthead and you will know who I mean.

The list that follows includes all the other expert reviewers whose services were generously provided and warmly received. I blame the computer if there are any omissions and offer my sincere apologies.

I B PLESS Editor

$\begin{array}{llll}\text { Reviewers 1998-999 } & & & \\ & & & \text { A Reeder } \\ \text { C Acton } & \text { C DiGuiseppi } & \text { L Laflamme } & \text { K Roche } \\ \text { C Alexander } & \text { C Finch } & \text { R Laporte } & \text { I Rootman } \\ \text { C Anderson } & \text { S Forjuoh } & \text { G Li } & \text { M Segui-Gomez } \\ \text { D van Aken } & \text { C Frangakis } & \text { J Little } & \text { S Sheps } \\ \text { L Banco } & \text { A German } & \text { C Macarthur } & \text { R Schieber } \\ \text { S Bangdiwala } & \text { D Girasek } & \text { S Mackenzie } & \text { J Sibert } \\ \text { D Bass } & \text { C Goulet } & \text { J Mayr } & \text { H Simpson } \\ \text { A Bergman } & \text { D Grossman } & \text { Y Mao } & \text { L Stallones } \\ \text { P Bijur } & \text { B Guyer } & \text { M Moffatt } & \text { M Stevenson } \\ \text { S Bremberg } & \text { Y Harel } & \text { B Morrongiello } & \text { S Stewart-Brown } \\ \text { R Byard } & \text { J Harrison } & \text { D Nelson } & \text { D Stueland } \\ \text { Y-F Chang } & \text { D Hemenway } & \text { C Neverman } & \text { D Stone } \\ \text { T Cheng } & \text { R Hingson } & \text { R Norton } & \text { D Thompson } \\ \text { M Chipman } & \text { J Howland } & \text { M Overpeck } & \text { G Vimpani } \\ \text { K Christoffel } & \text { B Jolly } & \text { J Ozanne-Smith } & \text { D Webster } \\ \text { C Coggan } & \text { A Kemp } & \text { P Parkin } & \text { P Wright } \\ \text { L Cohen-Barrios } & \text { T Klassen } & \text { C Peak-Asa } & \text { T Yamanaka } \\ \text { M Cordeiro } & \text { J Kotch } & \text { L Peterson-Homer } & \text { B Ytterstad } \\ \text { P Cummings } & \text { M Kramer } & \text { S Pratt } & \\ \text { C Currie } & \text { J Kraus } & \text { L Quan } & \\ \text { L Davidson } & \text { M Laffoy } & & \end{array}$

